\title{
Effects of natural factors (salinity and body weight) on cadmium, copper, zinc and metallothionein-like protein levels in resident populations of oysters Crassostrea gigas from a polluted estuary
}

\author{
C. Mouneyrac ${ }^{1, *}$, J. C. Amiard ${ }^{2}$, C. Amiard-Triquet ${ }^{2}$ \\ ${ }^{\text {I}}$ I.R.F.A. Département des Sciences de la Vie et de la Terre, Laboratoire d'Ecologie Animale, 44, Rue Rabelais, \\ F-49100 Angers, France \\ ${ }^{2}$ Université de Nantes, EP 61 du C.N.R.S., Faculté de Pharmacie, Service d'Ecotoxicologie, 1, Rue Gaston Veil \\ F-44035 Nantes, France
}

\begin{abstract}
The Gironde estuary has been shown to be the most Cd-contaminated area in France Oysters Crassostrea gigas of different size classes were sampled from 3 sites between the mouth and $25 \mathrm{~km}$ upstream, to study the relative importance of natural and contamination factors on metal accumulation and metallothionein-like protein (MTLP) induction. The highest metal and MTLP concentrations were observed in the digestive gland. In all organs, the 3 metals were mainly cytosolic. An inverse relationship was generally observed between weight of soft tissues and metals or MTLP concentrations in the whole soft tissues, whereas the influence of weight on metal distribution among cytosolic and insoluble fractions was small. When oysters with similar weight of soft tissues were considered, no influence of salinity at different sites was found for $\mathrm{Cu}$ and $\mathrm{Zn}$ whereas the lowest soluble and insoluble $\mathrm{Cd}$ concentrations were observed at the mouth of the river. Salinity did not influence $\mathrm{Cu}$ and $\mathrm{Zn}$ distribution among the cytosolic or insoluble fractions whereas cytosolic $\mathrm{Cd}$ in gills and digestive gland $(\%)$ was higher at the mouth of the estuary than upstream. MTLP and metal concentrations were generally positively correlated except at those sites where metal concentrations were lowest. However when multiple regression analyses were performed, weight appeared also as a major or an important factor to explain variations of MTLP levels, the prevalence of this natural factor versus contamination factors being different at different sites.
\end{abstract}

KEY WORDS: Oyster $\cdot$ Heavy metals $\cdot$ Metallothionein

\section{INTRODUCTION}

During the last decade, knowledge concerning chemical structure, biochemistry and ecological functions of metallothioneins has progressed. It is clear that these molecules play an initial role in the homeostasis of the essential metals $\mathrm{Zn}$ and $\mathrm{Cu}$, and are involved in detoxification of contaminants like $\mathrm{Cd}$ or $\mathrm{Hg}$ (Viarengo \& Nott 1993). It has been demonstrated that the incoming metals displace $\mathrm{Zn}$ from the pre-existing metallothioneins (Roesijadi \& Fellingham 1987, Viarengo et al. 1988). Moreover, it has been shown that metals such as $\mathrm{Cd}, \mathrm{Zn}$ and $\mathrm{Cu}$ can induce metallothionein synthesis in

\footnotetext{
•E-mail: cmouneyr@uco.fr
}

aquatic animals (Roesijadi 1992). Thus, metallothioneins have been proposed as indicators of trace metal pollution (George \& Olsson 1994).

Meanwhile, numerous studies supporting the idea that aquatic organisms synthesize metallothioneins as a defense against toxic metals are based on laboratory assays in which exposure conditions can differ greatly from those encountered in natural environments. In particular, metal concentrations shown to induce metallothionein synthesis in laboratory experiments are often several orders of magnitude higher than those found even in the most contaminated aquatic systems (Cosson et al. 1991, Couillard et al. 1993).

Moreover, in aquatic organisms such as molluscs, tissue metal concentrations can be highly dependent on 
environmental conditions and on the physiological status of individuals (Wright et al. 1985). Fowler et al. (1986) and Engel (1988) have reported changes in the binding of $\mathrm{Cd}$ and $\mathrm{Cu}$ by metallothioneins as a function of the reproductive stage in the oyster Crassostrea virginica. Another endogenous factor that must be considered is the weight of specimens (Cossa et al. 1980, Strong \& Luoma 1981). In the limpet Patella vulgata, concentrations of total and metallothionein-bound $\mathrm{Cd}$ are also correlated with size: larger individuals accumulate more total and metallothionein-bound $\mathrm{Cd}$ over their lifespans (Noël-Lambot et al. 1980). In contrast, in Macoma balthica and Mytilus edulis from Arctic estuaries, an inverse relationship has been shown between metallothionein concentrations and weight of soft tissues (Amiard-Triquet et al. in press).

Among natural factors, it is important to determine the influence of salinity on metal and on metallothionein concentrations in populations from estuaries which are submitted to salinity changes and have to acclimate to these modifications. Salinity influences metal level accumulation. Usually, decreasing salinities are associated with increasing metal body burdens and toxicity (Hall \& Anderson 1995). Roesijadi (1994), investigating the influence of salinity on bioaccumulation of $\mathrm{Cd}, \mathrm{Cu}$ and $\mathrm{Zn}$ in Crassostrea virginica from the Patuxent river (Maryland, USA), suggested this could be due to changes in metal speciation. This physicochemical change enhances the bioavailability of metal by decreasing the concentration of the free metal ion (Morisson 1989). However, in euryhaline species, there is a possibility that physiological adaptation, in particular osmoregulation processes, may influence the uptake of dissolved metals (Rainbow et al. 1993).

The ancient oyster-farming site of La Fosse in the Gironde estuary has been shown as the most Cd-contaminated marine area in France, so resident populations of oysters Crassostrea gigas from 3 sites in the Gironde estuary differing in salinity levels were selected in order to study the influence of body weight and salinity on $\mathrm{Cd}, \mathrm{Cu}$ and $\mathrm{Zn}$ accumulation and metallothionein induction

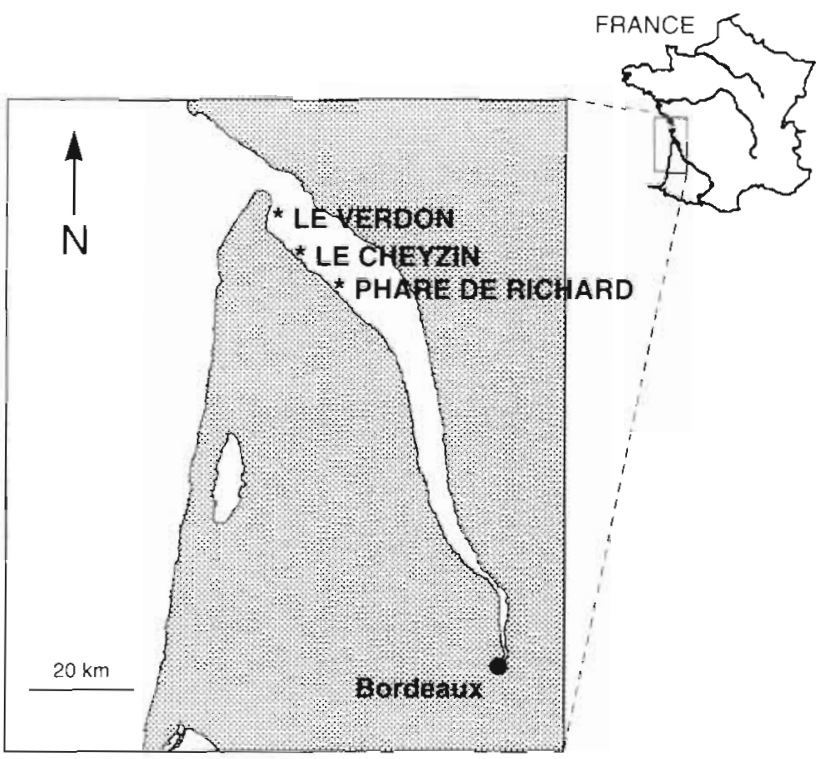

Fig. 1. Sampling sites (*) along the Gironde estuary, France

\section{MATERIALS AND METHODS}

Specimens. Three groups of Japanese oysters Crassostrea gigas were collected on 23 November 1995 from indigenous populations of bivalves at 3 locations on the Gironde estuary: (1) Le Verdon, (2) Le Cheyzin and (3) Phare de Richard (Fig. 1). These sites are located in the polyhaline area, the salinity of which is considered to vary between 18 and $30 \%$ (Castel et al. 1976). However, in the main channel, salinities varied from 7 to $17 \%$ at Phare de Richard, 13 to $25 \%$ at Le Cheyzin and 18 to $30 \%$ at Le Verdon (Allen 1972). We classified oysters into 2 class sizes according to the length of their shell and their total mass (shell and soft tissues): large oysters from Le Verdon and Le Cheyzin and small oysters from Le Verdon and Phare de Richard (Table 1). However, when oysters were dissected it appeared that the weight of soft tissues in 'small' oysters of Phare de Richard and 'large' oysters of Le Verdon were practically equal (Table 1 ).

Table 1. Crassostrea gigas. Wet weight ( $g$ ) of soft tissues of oysters sampled in the Gironde estuary. Means and confidence intervals at $95 \%$

\begin{tabular}{|c|c|c|c|c|}
\hline & \multicolumn{2}{|c|}{ Large oysters } & \multicolumn{2}{|c|}{ Small oysters } \\
\hline & $\begin{array}{l}\text { Le Verdon } \\
\qquad(\mathrm{n}=8)\end{array}$ & $\begin{array}{l}\text { Le Cheyzin } \\
\qquad(n=16)\end{array}$ & $\begin{array}{l}\text { Le Verdon } \\
\qquad(\mathrm{n}=8)\end{array}$ & $\begin{array}{l}\text { Phare de Richard } \\
\qquad(\mathrm{n}=8)\end{array}$ \\
\hline Total mass (shell and soft tissues) & $18.34 \pm 4.38$ & $23.52 \pm 5.73$ & $10.22 \pm 2.73$ & $11.06 \pm 3.61$ \\
\hline Gills & $0.34 \pm 0.10$ & $0.45 \pm 0.09$ & & \\
\hline Digestive gland & $0.18 \pm 0.04$ & $0.21 \pm 0.03$ & & \\
\hline Remainder & $0.62 \pm 0.17$ & $1.29 \pm 0.15$ & & \\
\hline Whole soft tissues & $1.14 \pm 0.28$ & $1.55 \pm 0.22$ & $0.42 \pm 0.07$ & $0.96 \pm 0.37$ \\
\hline
\end{tabular}


Under natural conditions, gonads are not developed at this time of the year, a fact which was verified in the present samples. Bivalves were frozen $\left(-20^{\circ} \mathrm{C}\right.$ if analysis was performed within $8 \mathrm{~d}$, otherwise $-80^{\circ} \mathrm{C}$ ) until analysis.

Metal compartmentation and determination. Dissection: The largest oysters (Le Verdon and Le Cheyzin) were thawed and dissected to isolate gills, digestive gland and remainder (i.e. mantle and muscle). The whole organ was recovered and weighed (Table 1). On the other hand, total soft tissues were used for the smallest specimens (Le Cheyzin and Phare de Richard).

Compartmentation (Fig. 2): Soft tissues from each individual organ or specimen were homogenized in $20 \mathrm{mM}$ TRIS, $150 \mathrm{mM} \mathrm{NaCl}$ solution adjusted to $\mathrm{pH}=$ 8.6 ( $4 \mathrm{ml} \mathrm{g}^{-1}$ soft tissue). The soluble and insoluble fractions were separated by centrifugation $(21250 \times g$ for $55 \mathrm{~min}$ ).

The soluble heat-stable thiolic compounds (metallothionein-like protein; MTLP) were isolated by centrifugation of the soluble fraction $(12000 \times \mathrm{g}$ for $10 \mathrm{~min})$ after heat-treatment $\left(75^{\circ} \mathrm{C}\right.$ for $\left.15 \mathrm{~min}\right)$.

$M T L P$ analysis: In the heat-denaturated cytosol (S2), the amount of MTLP was determined by differential pulse polarographic analysis (DPP); a technique based on thiolic (-SH) compound determination according to the Brdicka reaction (Brdicka 1933) as described by Thompson \& Cosson (1984). A PAR Model 174 analyser, a PAR/EG\&G Model 303 static mercury drop electrode (SMDE) and an X-Y recorder (RE 0089) were used. The temperature of the cell was maintained at $5^{\circ} \mathrm{C}$. The standard addition method was used for calibration with rabbit liver metallothionein (MT) (Sigma Chemical Co., St Louis, MO, USA) in the absence of oyster MT standard.

Metal analysis: Nalgene bottles were used to store all reagents. All labware was soaked in 10\% hydrochloric acid, rinsed 3 times with deionized water and dried in a desiccator sheltered from atmospheric dusts. The insoluble (C1) and soluble (S1) fractions were heated $\left(80^{\circ} \mathrm{C} ; 1 \mathrm{~h}\right.$ ) with suprapur nitric acid (Carlo Erba) ( $1 \mathrm{ml}$ per $1 \mathrm{ml} \mathrm{S} 1 ; 1 \mathrm{ml}$ per $0.5 \mathrm{~g} \mathrm{C} 1$ ). After digestion, metal levels in these acid solutions were determined, after dilution with deionized water, by flame atomic absorption spectrophotometry using the Zeeman effect (Hitachi Z 8200 spectrophotometer). The analytical method has been described previously by Amiard et al. (1987a).

Fig. 2. Procedure of metal compartmentation and MTLP (metallothionein-like protein) determination in soft tissues of oysters
Table 2. Results of external quality control (mean concentrations and standard deviations in $\mathrm{mg} \mathrm{kg} \mathrm{k}^{-1}$ dry wt) (Coquery \& Horvat 1996: [AEA-MEDPOL)

\begin{tabular}{|c|c|c|c|}
\hline & $\mathrm{Cd}$ & $\mathrm{Cu}$ & $\mathrm{Zn}$ \\
\hline \multicolumn{4}{|c|}{ Fish homogenate (MA-MEDPOL-1/TM) } \\
\hline Our value & $0.0021(0.0007)$ & $0.66(0.10)$ & $17.3(0.6)$ \\
\hline Certified value & $0.015(0.012)$ & $0.62(0.12)$ & $16.80(0.48)$ \\
\hline Z-scores ${ }^{\mathrm{a}}$ & -1.1 & 0.3 & 0.2 \\
\hline \multicolumn{4}{|c|}{ Marine sediment (SD-MEDPOL-1/TM) } \\
\hline Our value & $0.70(0.06)$ & $23.9(1.4)$ & $189.0(2.3)$ \\
\hline Certified value & $0.59(0.10)$ & $25.1(3.8)$ & $191(17)$ \\
\hline Z-scores ${ }^{a}$ & 1.5 & -0.4 & -0.1 \\
\hline \multicolumn{4}{|c|}{$\begin{array}{l}\alpha|Z| \leq 2 \text { : performance is acceptable (Thompson \& Wood } \\
1993 \text { ) }\end{array}$} \\
\hline
\end{tabular}

Standard addition analysis was performed in an isomedium and concentrations of each element were $+125,250,500 \mathrm{ng} \mathrm{Cu}$ and $\mathrm{Zn} \mathrm{ml}^{-1}$ and $+62.5,125$,

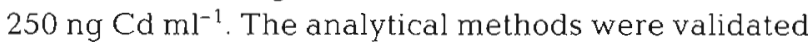
by external intercalibrations (Coquery \& Horvat 1996) (Table 2).

Total metal concentrations in each organ (large oysters) or in the whole soft tissue (small oysters) were recalculated from quantities of trace elements in soluble and insoluble fractions determined previously. Metal and MTLP concentrations in the whole soft tissues of the large oysters were recalculated by adding quantities in each organ divided by the sum of weights.

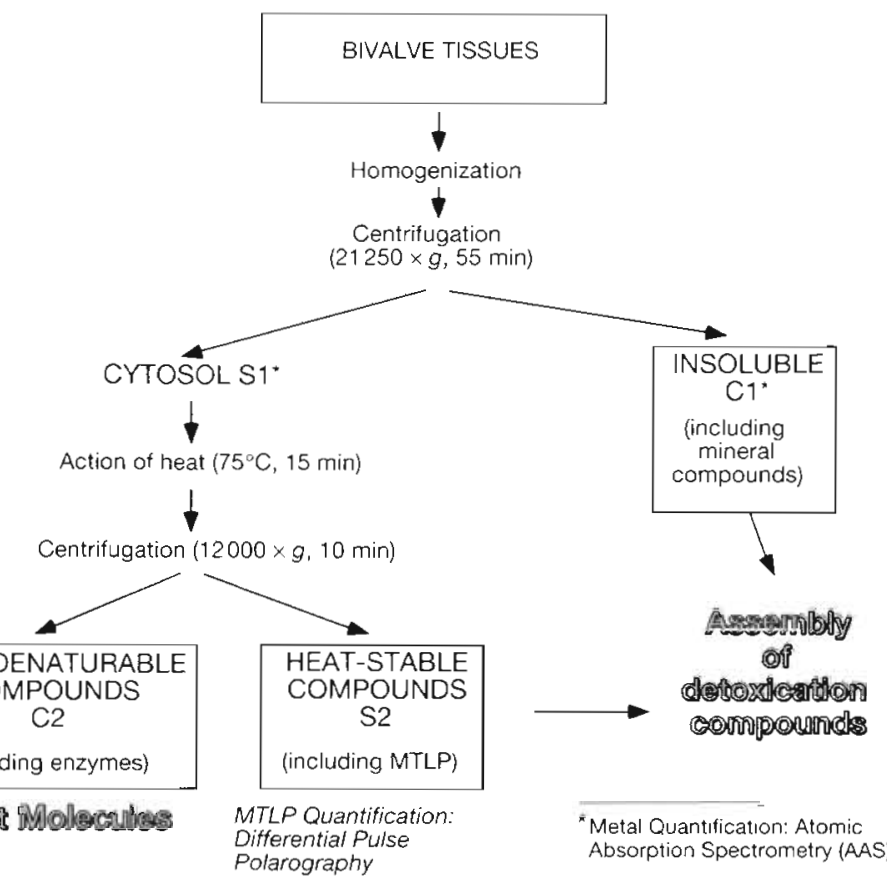


Statistical treatment. Comparisons of 2 series (Student's test) and regression analysis (linear or multiple) were carried out using a standard statistical package (StatView $\mathrm{SE}^{+}$Graphics $M$ ). Comparisons of 3 series (Tukey's test) were performed with Statgraphics Plus (version 2)

When MTLP (dependent variable) was expressed as a function of metal concentrations and body weight. (independent variables), a standardization of the independent variables was needed to avoid the problem of unit. The proposed method is to transform natural variables $x_{i}(\mathrm{Cd}, \mathrm{Cu}, \mathrm{Zn}$ and body weight) into coded variables $X_{1}$ :

$$
\text { MTLP }=\alpha_{0}+\sum \alpha_{i} X_{i}
$$

$X_{j \max }=+1$ for the maximum value of a variable, and $X_{i \min }=-1$ for the minimum value. The passage for natural variables to coded variables is given by the following equations (Montgomery \& Peck 1982):

$$
X_{i}=\frac{x_{i}-\left(x_{i \max }+x_{i \min }\right) / 2}{\left(x_{i \max }-x_{i \min }\right) / 2}
$$

where $x_{i m n}$ is the lowest value of the natural variable, and $x_{1 \text { max }}$ is the highest value of the natural variable.

The model coefficients $\left(\alpha_{0}, \alpha_{1}, \alpha_{2}, \alpha_{3}, \alpha_{4}\right)$ were estimated by the StatView program. These coefficients were tested by using the Student's test.

\section{RESULTS}

\section{Organotropism}

Gross concentrations and body burdens of trace metals. The distribution of trace metals and MTLP among gilis (G), digestive gland (DG) and remainder $(R)$ was studied in large oysters from Le Verdon and Le Cheyzin.

At both sites, the highest $\mathrm{Cd}, \mathrm{Cu}$ and $\mathrm{Zn}$ concentrations were generally shown in the digestive gland whatever the fraction considered (Fig. 3a).

Considering body burdens, $\mathrm{Cd}$ and $\mathrm{Zn}$ were mainly stored in remainder. On the other hand, for $\mathrm{Cu}$ the most striking feature was the different main storage site in oysters from Le Verdon and from Le Cheyzin: gills in the first case and remainder in the second (Fig. 3b).

Trace metal compartmentation. The quantity of each metal in each fraction (soluble S1 or insoluble C1) is expressed as a percentage of the total quantity of metal in the whole tissue ( $\mu \mathrm{g}$ per individual). In all organs or group of organs, the 3 metals were mainly cytosolic (Table 3). The percentage of $\mathrm{Cu}$ present in the soluble fraction was constant, whereas for $\mathrm{Cd}$ and $\mathrm{Zn}$, significant differences were observed (Tukey's test, $\alpha=0.05$ ) (Table 3).
Table 3. Crassostrea gigas. Percentage of cytosolic metals in gills (G), digestive gland (DG) and remainder (R) of oysters originating from 2 estuarine sites. Means and confjdence intervals at $95 \%$ for $n=8$ (Le Verdon) and $n=16$ (Le Cheyzin). Means with same superscripts are not significantly

\begin{tabular}{|c|c|c|c|c|c|c|}
\hline \multirow{2}{*}{ Metal } & \multicolumn{3}{|c|}{ Le Verdon } & \multicolumn{3}{|c|}{ Le Cheyzin } \\
\hline & $\mathrm{G}$ & DG & $\mathrm{R}$ & $\mathrm{G}$ & $\mathrm{DG}$ & $\mathrm{R}$ \\
\hline $\mathrm{Cd}$ & $76 \pm 5^{a, b}$ & $83 \pm 6^{b}$ & $73 \pm 7^{a}$ & $71 \pm 6^{r}$ & $64 \pm 5^{\mathrm{c} d}$ & $60 \pm 2^{d}$ \\
\hline $\mathrm{Cu}$ & $62 \pm 4^{e}$ & $68 \pm 4^{\circ}$ & $62 \pm 7^{6}$ & $65 \pm 8^{1}$ & $65 \pm 8^{f}$ & $65 \pm 4^{f}$ \\
\hline $\mathrm{Zn}$ & $76 \pm 5$ & $83 \pm 2$ & $60 \pm 5$ & $73 \pm 3^{9}$ & $72 \pm 8^{9}$ & $56 \pm 3$ \\
\hline
\end{tabular}
different from each other (Tukey's test: $p<0.05$ )

MTLP in the 2 organs (gills and digestive gland) and remainder. MTLP concentrations (Fig. 3c) were significantly higher (at the $95 \%$ confidence level with Tukey's test) in the digestive gland than in gills and remainder of oysters from Le Verdon $(n=8)$. In oysters from Le Cheyzin (Fig. 3c), MTLP concentrations were significantly different in all compartments (Tukey's test, $\alpha=0.05): R<G<D G$.

\section{Influence of weight}

Influence of weight on trace metal and MTLP concentrations in whole soft tissue. Metal and MTLP concentrations in whole soft tissues of the large oysters were calculated from the sum of quantities of metals and MTLP in isolated organs divided by the weight of the whole soft tissue

A significant inverse $(\alpha=0.01)$ relationship was observed between weight and MTLP concentrations for oysters from all 3 sites (Fig. 4).

$\mathrm{Cd}, \mathrm{Cu}$ and $\mathrm{Zn}$ concentrations in the soluble fraction (S1) were negatively correlated to weight $(p<0.01)$ except for $\mathrm{Cd}$ at Le Verdon (Fig. 5).

Concerning the insoluble fraction (C1), the results were similar, the among-site differences leading to a non-significant correlation between $\mathrm{Cd}$ concentration and weight (Fig. 5).

Influence of weight on metal distribution between soluble and insoluble fractions. The percentage of soluble metals was determined directly in whole soft tissues for small oysters from Le Verdon and Phare de Richard. For large oysters from Le Verdon and Le Cheyzin, this percentage was recalculated from data obtained with isolated organs.

No significant correlation was found between the percentage of soluble metals in the whole soft tissues and their weight (these percentages were constant).

However, when the influence of size was examined independently of any other factor, as was possible for oysters originating from Le Verdon, the percentage of 
a Le Verdon
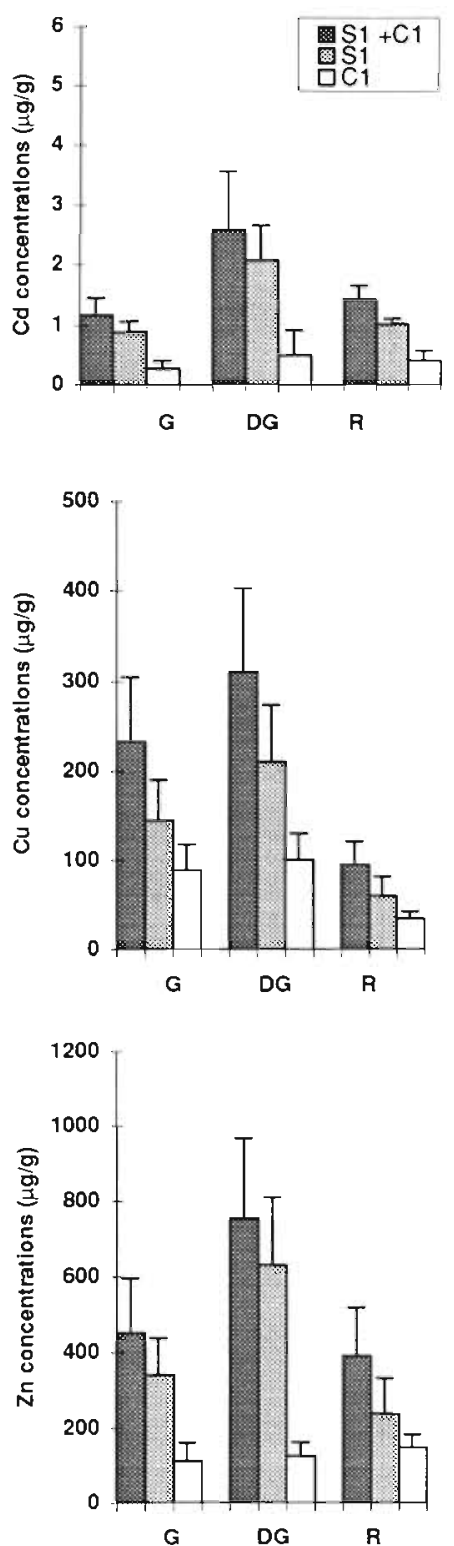

Le Cheyzin
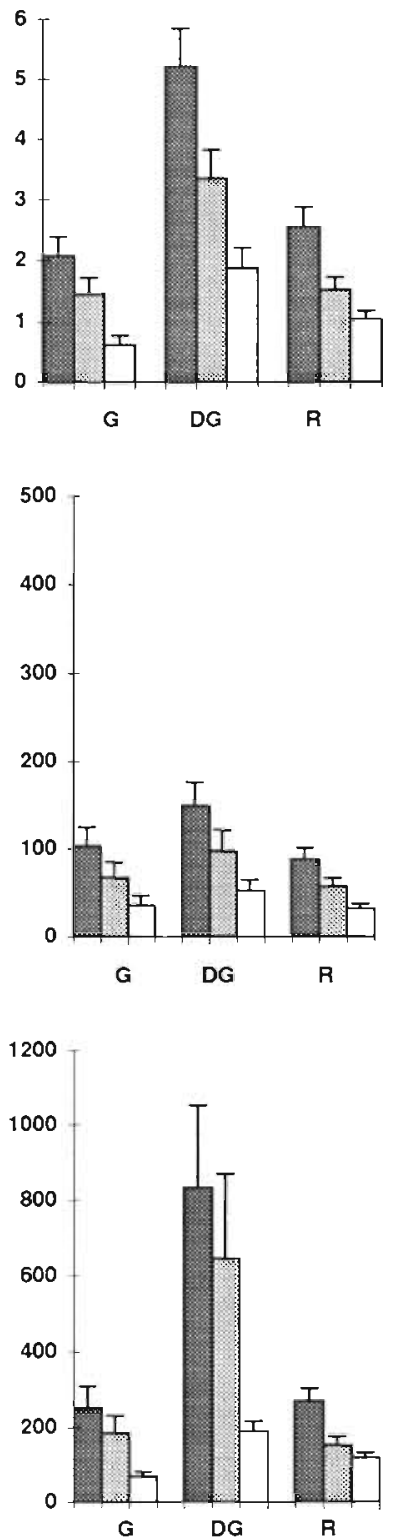

Fig. 3. Crassostrea gigas. (a) $\mathrm{Cd}, \mathrm{Cu}$ and $\mathrm{Zn}$ concentrations (means and confidence intervals at $95 \%$ level) and (b) $\mathrm{Cd}, \mathrm{Cu}$ and $\mathrm{Zn}$ body burdens (means in $\mu \mathrm{g}$ per individual and confidence intervals at $95 \%$ level) in the soluble (S1) and insoluble (C1) fractions in whole organs or groups of organs. (c) MTLP concentrations (means and confidence intervals at $95 \%$ level) in heat-denatured cytosol in organs. Oysters from Le Verdon $(n=8)$ and Le Cheyzin $(n=16)$. G: gills; DG: digestive gland; $R$ : Iemainder
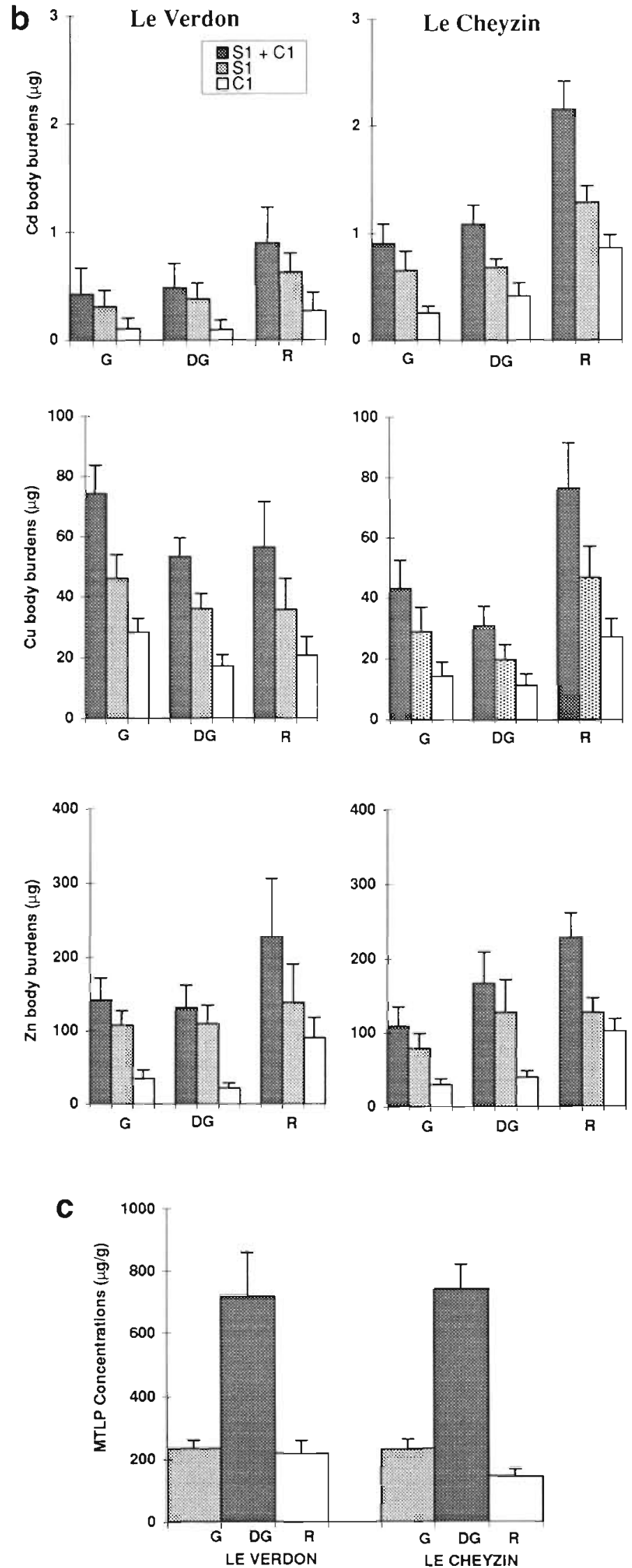


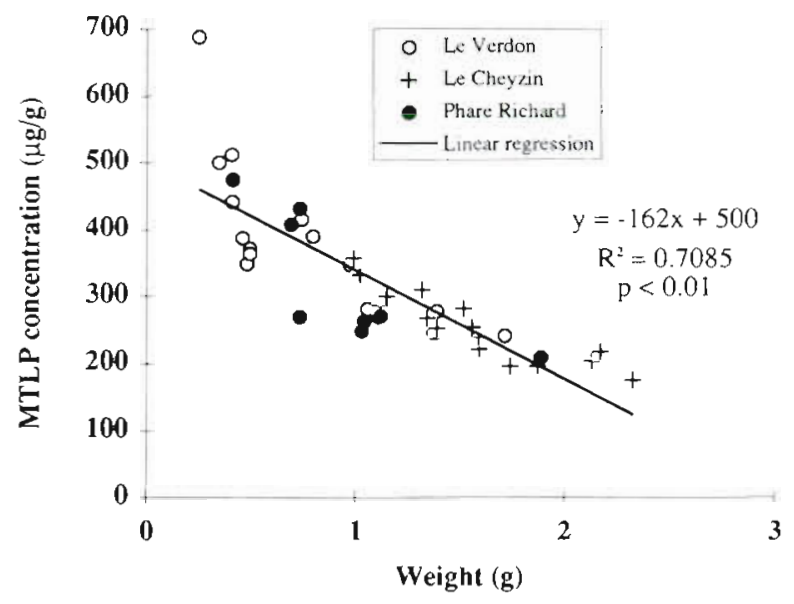

Fig. 4. Crassostrea gigas. Influence of weight on MTLP concentrations in the whole soft tissues of individual oysters at different sites in the Gironde estuary concentration remained constant with increasing weight at Le Verdon. From Fig. 5, this site, characterized by the highest salinity, is clearly different from the other 2 sites by having the lowest levels of $\mathrm{Cd}$ in both soluble and insoluble fractions

Influence of salinity on trace metal compartmentation. The influence of salinity was examined by using Tukey's test to compare the percentages of cytosolic metals (S1) in oysters showing similar wet weight of soft tissues (Table 4 , columns 2 to 4 ). When the whole soft tissues were considered, the influence of salinity was generally negligible except in the case of $\mathrm{Cd}$ (Table 4). These differences were partly due to higher percentages of cytosolic $\mathrm{Cd}$ in digestive glands and remainder (Student's test; $\mathrm{p}<0.01$ ) in oysters from Le Verdon (respectively $83 \pm 6$ and $73 \pm 7 \%$ ) compared to Le Cheyzin (respectively $64 \pm 5$ and $60 \pm 2 \%$; Table 3 ). cytosolic Zn was significantly higher in large oysters $(71 \pm 3 \%)$ than in small ones $(59 \pm 6 \%)$ (Table 4$)$.

\section{Influence of salinity}

Influence of salinity on trace metals and MTLP concentrations. In Figs. 4 $\& 5$, the data corresponding to the 3 estuarine sites have been differentiated. For MTLP (Fig. 4), soluble (S1) and insoluble (C1) $\mathrm{Cu}$ and $\mathrm{Zn}$ concentrations (Fig. 5), no differences appeared among sites when individuals with similar weight of soft tissues were considered. On the other hand, the relationships between soluble and insoluble $\mathrm{Cd}$ concentrations versus weight of soft tissues were influenced by the sampling site (Fig. 5). At Phare de Richard, a logarithmic relationship was shown but it was significant only for cytosolic Cd. For both S1 and C1. a significant linear relationship was depicted at Le Cheyzin, whereas Cd

Fig. 5. Crassostrea gigas. Influence of weight on metal concentrations in the soluble and insoluble fractions of whole soft tissues of individual oysters. A linear regression is depicted for all 3 sites in the case of $\mathrm{Cu}$ and $\mathrm{Zn}$, whereas the relationship is influenced by site for Cd (see comments in the text)

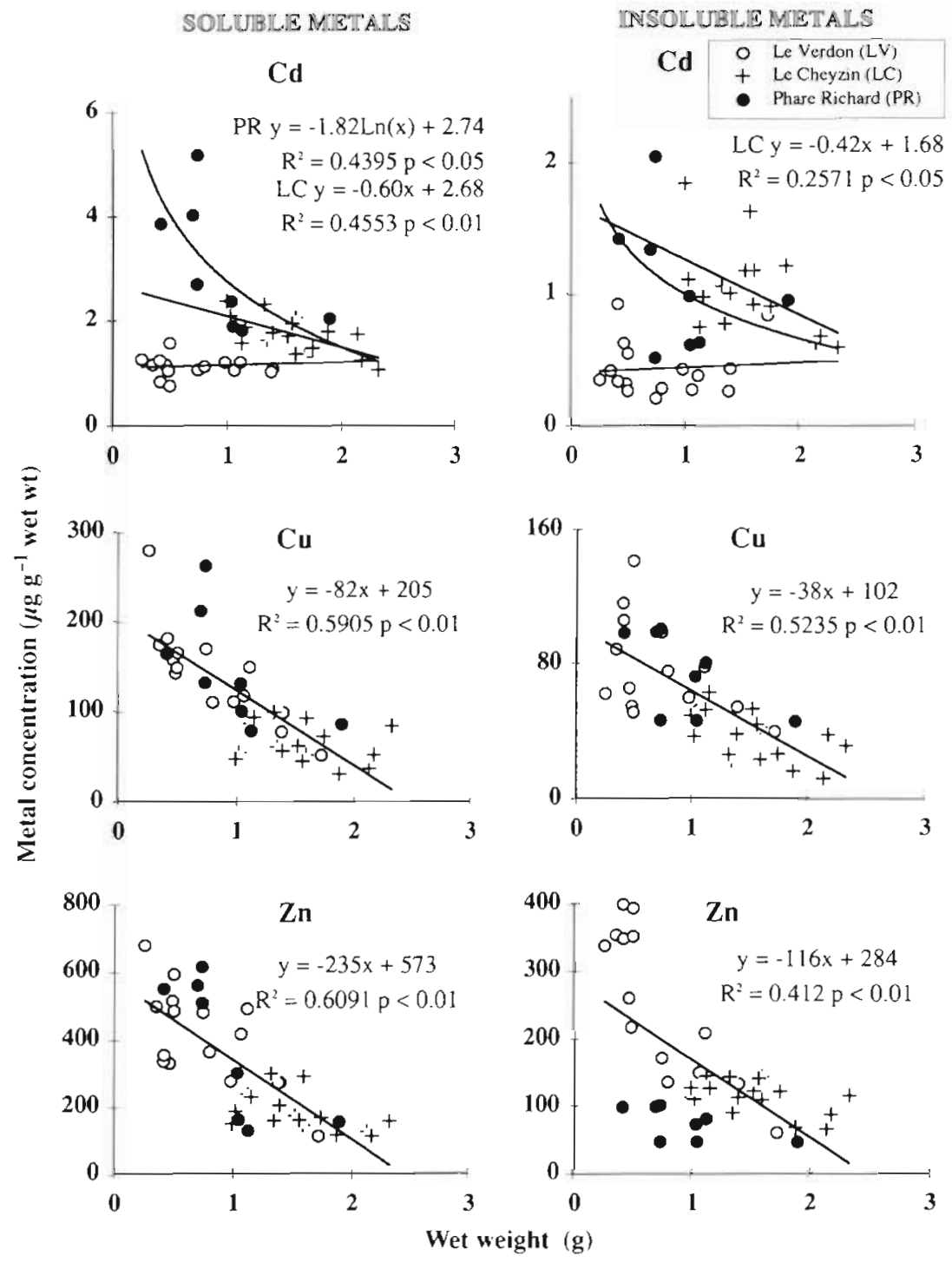


Table 4. Crassostrea gigas. Percentage of cytosolic metals in soft tissues of oysters from 3 estuarine sites (columns 1 and 4 determined in whole soft tissues; columns 2 and 3: recalculated from data for isolated organs). Means and confidence intervals at $95 \%$. Means with same superscripts are not significantly different from each other (Tukey's test; $p<0.05$ )

\begin{tabular}{|ccccc|}
\hline & $\begin{array}{c}(1) \\
\text { Le Verdon } \\
\text { Small }\end{array}$ & $\begin{array}{c}\text { Le Verdon } \\
\text { Large }\end{array}$ & $\begin{array}{c}(3) \\
\text { Le Cheyzin }\end{array}$ & $\begin{array}{c}(4) \\
\text { Phare de } \\
\text { de Richard }\end{array}$ \\
\hline $\mathrm{Cd}$ & $71 \pm 6^{\mathrm{a}}$ & $76 \pm 5^{\mathrm{a}}$ & $64 \pm 3$ & $74 \pm 4^{\mathrm{a}}$ \\
$\mathrm{Cu}$ & $68 \pm 7^{\mathrm{b}}$ & $64 \pm 3^{\mathrm{o}}$ & $64 \pm 5^{\mathrm{b}}$ & $66 \pm 6^{\mathrm{b}}$ \\
$\mathrm{Zn}$ & $59 \pm 6$ & $71 \pm 3^{\mathrm{c}}$ & $65 \pm 4^{\mathrm{c}}$ & $63 \pm 7^{\mathrm{c}}$ \\
\hline
\end{tabular}

\section{Relationships between trace metal and MTLP concentrations}

\section{Linear regression analysis}

According to the hypothesis that MTLP is a major sink for bioaccumulated metals, it should be preferable to examine metal versus MTLP levels taking into account metal concentrations in the supernatant $S_{2}$ obtained after heat-denaturation of the cytosol and containing heat-stable compounds including MTLP. However, the fate of metals during heating is a matter of question and so we have depicted in Fig. 6 metal levels in cytosol $\mathrm{S}_{1}$ versus MTLP.

These factors were generally correlated positively but the correlations were not significant for $\mathrm{Cd}$ in oysters originating from Le Verdon and for $\mathrm{Cu}$ and $\mathrm{Zn}$ in oysters from Le Cheyzin (Fig. 6), i.e. at those sites where the concentrations of each metal were lowest.

With a view to its use as a biomarker, metallothionein has to reflect the gross metallic concentration in a particular compartment. In the present study, the relationships between metal levels in the whole soft tissues ( $\mathrm{S} 1+\mathrm{C} 1)$ and MTLP (not shown) were similar to those depicted in Fig. 6 for cytosolic metals.

\section{Multiple regression analysis}

In order to compare the relative importance of a natural source of variation (weight, $W$ ) and contamination factors, multiple regression analyses were performed to express MTLP as a function of metal concentrations $\left(\mu \mathrm{g} \mathrm{g}^{-1}\right)$ and weights (the variables were standardized):

$$
\mathrm{MTLP}=f(\mathrm{Cd}, \mathrm{Cu}, \mathrm{Zn}, W)
$$

The results are presented by the following models for each estuarine site. The significance of each coefficient (probability based on t-test) is shown in parentheses.
Le Verdon, $n=16, r=0.914$ :

$$
\begin{array}{r}
\text { MTLP }=-0.21+0.109 \mathrm{Cd}+0.9 \mathrm{Cu}-0.16 \mathrm{Zn}-0.19 \mathrm{~W} \\
(\mathrm{p}=0.43) \quad(\mathrm{p}=0.006) \quad(\mathrm{p}=0.29) \quad(\mathrm{p}=0.34)
\end{array}
$$

$\mathrm{Cu}$ concentration appeared as the only significant factor affecting MTLP level. When a stepwise regression analysis was performed, Cu was shown to explain $88.6 \%$ of MTLP variation.

Le Cheyzin, $n=16, r=0.929$ :

$$
\begin{aligned}
& \text { MTLP }= \\
& -0.414+0.508 \mathrm{Cd}+0.385 \mathrm{Cu}-0.448 \mathrm{Zn}-0.498 \mathrm{~W} \\
& \qquad(p=0.06) \quad(p=0.17) \quad(p=0.10) \quad(p=0.03)
\end{aligned}
$$

Weight appeared as the major significant factor affecting MTLP level, followed by $\mathrm{Cd}$ concentration and, when a stepwise regression analysis was per-
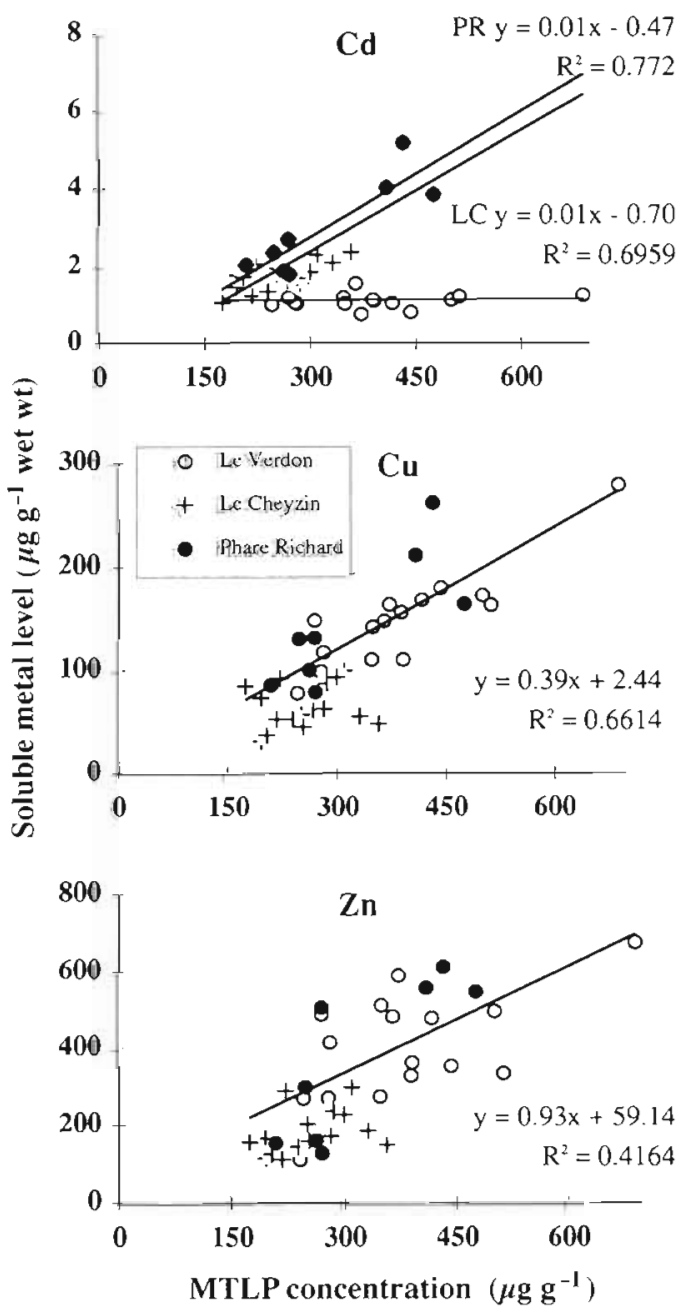

Fig. 6. Crassostrea gigas. Relationship between MTLP concentrations and soluble metal levels in whole soft tissues of individual oysters. Samples from Le Verdon have been eliminated from the regression in the case of $\mathrm{Cd}$; Le Cheyzin in the case of $\mathrm{Cu}$ and $\mathrm{Zn}$ 
formed, weight alone was shown to explain $89.6 \%$ of MTLP variation.

Phare de Richard, $n=8, r=0.978$ :

$$
\begin{array}{r}
\text { MTLP }=0.24+2.18 \mathrm{Cd}-0.375 \mathrm{Cu}-0.47 \mathrm{Zn}-0.72 \mathrm{~W} \\
(\mathrm{p}=0.04) \quad(\mathrm{p}=0.13) \quad(\mathrm{p}=0.23) \quad(\mathrm{p}=0.06)
\end{array}
$$

Cd concentration appeared as the major significant factor affecting MTLP level, followed by weight and, when a stepwise regression analysis was performed, $\mathrm{Cd}$ alone was shown to explain $87.9 \%$ of MTLP variation.

\section{DISCUSSION}

The high concentrations of $\mathrm{Cd}, \mathrm{Zn}$ and $\mathrm{Cu}$ in oysters of the Gironde estuary are consistent with previous reports of elevated metal concentrations in natural populations of this area (RNO 1995). The digestive gland accumulates more trace metals than the gills and remainder in both soluble and insoluble fractions in oysters from the 3 studied estuarine sites. These results are in accordance with those of Martincić et al. (1984) and Frew et al. (1989) for Cd, and Martincić et al. (1986, 1987) for $\mathrm{Cu}$ and $\mathrm{Zn}$ in Ostrea edulis. In contrast. Rajendran et al. (1988) mentioned that the gills accumulate more $\mathrm{Cu}$ and $\mathrm{Zn}$ than the visceral mass in Crassostrea madrasensis. In the present study MTLP levels were shown to be higher in the digestive gland than in the gills and the remainder. A similar distribution has been shown in the clam Ruditapes decussatus (Bebianno et al. 1993).

In oysters of the Gironde estuary, $\mathrm{Cd}, \mathrm{Cu}$ and $\mathrm{Zn}$ were mainly cytosolic in all organs. This is in accordance with previous studies on bivalves (Langston \& Zhou 1987, Pavicic et al. 1989, Evtushenko et al. 1990). In contrast, the soluble fraction represented only 23 and $28 \%$ of gill $\mathrm{Cu}$ and $\mathrm{Zn}$ concentrations in natural populations of Crassostrea virginica of the Patuxent River studied by Roesijadi (1994). The relative importance of cytosolic $\mathrm{Cd}$ was highly variable according to site and season (29 to $66 \%$ ) but values were always lower than the values determined in the Gironde estuary. The cytosolic fraction includes both metals bound to MTLP and/or high molecular weight (HMW) compounds. Carpène \& George (1981) have proposed that metal ions bind first to specific HMW proteins that act as intra-cellular carrier molecules. Once bound to these carrier molecules, the metals would follow pathways that eventually lead to the observed metal distribution which includes binding to MTLP and other cellular compounds. These observations have been also reported by Evtushenko et al. (1986) for the scallop Mizuhopecten yessoensis, by Couillard et al. (1995) for a freshwater bivalve Pyganodon grandis, and by Mouneyrac et al. (1995) for C. gigas.
In the present study, MTLP and metal concentrations-either in the cytosol or in the whole soft tissues - were generally positively correlated, with the exceptions of those sites where metal concentrations were lowest. In Crassostrea virginica, the cytosalic concentrations of $\mathrm{Cd}, \mathrm{Cu}$ and $\mathrm{Zn}$ significantly affected the levels of MT-bound $\mathrm{Cd}$ and $\mathrm{Zn}$ whereas MT-bound $\mathrm{Cu}$ did not exhibit a similar relationship. A strong linear relationship between cytosolic and MT-bound Cd has been also reported in natural populations of other molluscs (Noël-Lambot et al. 1980, Johansson et al. 1986). Moreover, according to Johansson et al. (1986), the concentration of metals in cytosol usually reflects the concentration in the whole tissues, although variability has been noted when the concentrations are low.

Due to the high percentage of metals in the cytosol and to the strong relationship between metal and MTLP levels, the use of MTLP as a biomarker of metal pollution seems dependable if oysters are chosen as the support for the determination of this biochemical parameter.

However, weight appears also as an important factor to explain variations of MTLP levels, the prevalence of this natural factor versus contamination factors being different at different sites in the Gironde estuary. The inverse relationships generally observed between weight and metals or MTLP concentrations in the whole soft tissues in the present work are in accordance with previous studies in oysters (Phelps et al. 1985, Phelps \& Hetzel 1987. Amiard et al. 1994). A theoretical profile describing the relationship between metal concentrations and tissue weights has been proposed by the US NRC (1980). Immature animals showed an inverse relationship between tissue weight and concentration, whereas in mature individuals seasonal variability interfered with the influence of weight. Similarly, in Crassostrea gigas Zn concentration decreased during the first year of life but then increased until the end of the study (42 mo) (Berthet 1986). The relationship between weight and MTLP may be indirect as a consequence of the influence of weight on metal levels.

Salinity appears to be a natural factor influencing metal levels (Phelps et al. 1985, Amiard-Triquet et al. 1991, Roesijadi 1994) and is thus potentially able to interfere with MT levels. No influence of salinity at different sites in the Gironde estuary was found for $\mathrm{Cu}$ and $\mathrm{Zn}$ whereas the lowest soluble and insoluble $\mathrm{Cd}$ concentrations were observed at the mouth of the river (i.e. the site showing the highest salinity). Salinity did not influence $\mathrm{Cu}$ and $\mathrm{Zn}$ distribution among the cytosolic or insoluble fractions whereas cytosolic $\mathrm{Cd}$ in gills and digestive gland was higher at the mouth of the estuary than upstream. In Crassostrea virginica, 
$\mathrm{Cd}$ and $\mathrm{Cu}$ concentrations in the gills increased upstream from the mouth of the Patuxent River whereas the tendency for $\mathrm{Zn}$ was not so strong (Roesijadi 1994). These results are similar to those reported here for $\mathrm{Cd}$ and $\mathrm{Zn}$ in $\mathrm{C}$. gigas from the Gironde estuary but no relationship of $\mathrm{Cu}$ concentration with position in the river was found. This discrepancy may be due to the fact that $\mathrm{Cd}$ and $\mathrm{Zn}$ levels in oysters were of the same order of magnitude in both estuaries whereas $\mathrm{Cu}$ levels in oysters were about an order of magnitude higher in the Gironde estuary.

Chemical speciation of metals as well as biological processes may intervene to govern bioaccumulation changes associated with salinity. According to Wright \& Zamuda (1987), the salinity effect is independent of cupric ion activity. Moreover, chemical speciation of $\mathrm{Cu}$ in estuaries is mainly governed by organic ligands (Mantoura et al. 1978). In the Gironde estuary, the level of dissolved organic carbon decreased downstream (Etcheber 1983), suggesting a higher bioavailability of $\mathrm{Cu}$ at the mouth of the river. On the other hand, the bioavailability of $\mathrm{Cd}$ and $\mathrm{Zn}$ decreases as salinity increases due to increased chloride ion complexation but the phenomenon is much more marked for Cd than for Zn (Zirino \& Yamamoto 1972, Mantoura et al. 1978), as shown by stability constants (Turner et al. 1981). Depledge (1990) and Chan et al. (1992) suggested that euryhaline invertebrates may adapt to brackish water through changes in water and electrolyte permeability which could interfere with trace metal uptake. In the case of the Gironde estuary, it may be hypothesized that, although $\mathrm{Zn}$ bioavailability increases for a given salinity drop, the oysters became increasingly impermeable to $\mathrm{Zn}$ to such an extent that overall uptake of $Z n$ fell. Due to the contrasting biological role of $\mathrm{Zn}$ (essential) and $\mathrm{Cd}$ (toxic), it has been shown previously that regulation of their uptake was clearly different in various invertebrates (Amiard et al. $1987 \mathrm{~b}$ and literature cited therein).

In conclusion, measuring the levels of metallothioneins in oysters appears to be an interesting monitoring procedure to assess biological availability of metals in estuarine and coastal areas, provided that the influence of natural factors is taken into account. Concerning weight and salinity, the necessary steps may be derived from those which have been extensively described in the framework of the 'Mussel Watch' when metal concentrations in bivalves were proposed as bioindicators of metal pollution (NRC 1980). It will be also necessary to improve the assessment of seasonal changes of MT levels in relation to metal concentrations and weight fluctuations which have been well documented (NRC 1980). Concerning possible seasonal changes of $\mathrm{MT}$, a seasonal cycling of Cd-binding between MTLP and intra-cellular granules (also involved in detoxication; Mason \& Jenkins 1995) has been shown in some molluscan species (Bouquegneau et al. 1984).

Acknowledgements. The authors thank J. M. Cornevin for his technical assistance.

\section{LITERATURE CITED}

Allen GP (1972) Etude des processus sédimentaires dans l'estuaire de la Gironde. Thèse de Doctorat d'Etat es Sciences, Université de Bordeaux I

Amiard JC, Amiard-Triquet C, Berthet B, Métayer C (1987b) Comparative study of the patterns of bioaccumulation of essential $(\mathrm{Cu}, \mathrm{Zn})$ and non-essential $(\mathrm{Cd}, \mathrm{Pb})$ trace metals in various estuarine and coastal organisms. J Exp Mar Biol Ecol 106:73-89

Amiard JC, Métayer C, Baud JP, Ribeyre F (1994) Influence of some ecological and biological factors on metal bioaccumulation in young oysters (Crassostrea gigas Thunberg) during their spat rearing. Wat Res 28 (1):219-231

Amiard JC, Pineau A, Boiteau HL, Métayer C, AmiardTriquet C (1987a) Application of atomic absorption spectrophotometry using Zeeman effect to the determination of eight trace elements ( $\mathrm{Ag}, \mathrm{Cd}, \mathrm{Cr}, \mathrm{Cu}, \mathrm{Mn}, \mathrm{Ni}, \mathrm{Pb}$ and $\mathrm{Se}$ ) in biological materials. Wat Res 21(6):693-697

Amiard-Triquet C, Berthet B, Martoja R (1991) Influence of salinity on trace metal ( $\mathrm{Cu}, \mathrm{Zn}$, Ag) accumulation at the molecular, cellular and organism level in the oyster Crassostrea gigas Thunberg. Biol Metals 4:144-150

Amiard-Triquet $C$, Rainglet $F$, Larroux C, Regoli F, Hummel $\mathrm{H}$, Marjolina $\mathrm{S}$ (in press) Metallothioneins in arctic bivalves. Ecotoxicol Environ Saf

Bebianno MJ, Nott JA, Langston WJ (1993) Cadmium metabolism in the clam Ruditapes decussata: the role of metallothioneins. Aquat Toxicol 27:315-334

Berthet B (1986) Etudes in situ et expérimentales du devenir de quelques éléments métalliques $(\mathrm{Cd}, \mathrm{Pb}, \mathrm{Cu}$ et $\mathrm{Zn}$ ) dans un écosystème de zone conchylicole. Thèse de Doctorat d'Etat es Sciences, Université de Rennes I

Bouquegneau JM, Martoja M. Truchet M (1984) Heavy metals storage in marine animals under various environmental conditions. In: Bolis L, Zadunaisky J, Gilles R (eds) Toxins, drugs, and pollutants in marine animals. SpringerVerlag, Heidelberg, p 147-160

Brdicka A (1933) Polarographic studies with the dropping mercury method. A new test for proteins in the presence of cobalt salts in ammoniacal solution of ammonium chloride. Collect Czech Chem Commun 5:112-128

Carpène E, George SJ (1981) Absorption of Cd by gills of Mytilus edulis (L). Mol Physiol 1:23-24

Castel J, Arzul G, Lissalde JP (1976) Etude prélıminaire du plancton de l'estuaire de la Gironde. J Rech Océanogr $1(2): 17-24$

Chan HM, Bjerregaard P, Rainbow PS, Depledge MH (1992) Uptake of zinc and cadmium by two populations of shore crabs Carcinus maenas at different salinities. Mar Ecol Prog Ser 86:91-97

Coquery M, Horvat M (1996) The analytical performance study for the MED POL area: determination of trace-elements in marine sediment SD-MEDPOL-1/TM and fish homogenate MA-MEDPOL-1/TM. Report IAEA, Monaco

Cossa D, Bourget E, Pouliot D, Piuze J, Chanut JP (1980) Geographical and seasonal variations in the relationship between trace metal content and body weight in Mytilus edulis. Mar Biol 58:7-14 
Cosson RP, Amiard-Triquet C, Amiard JC (1991) Metallothioneins and detoxication. Is the use of detoxication protein for MTS a language abuse? Water Air Soil Pollut 57-58: $555-567$

Couillard Y, Campbell PGC, Pellerin-Massicote J, Auclair JC (1995) Field transplantation of a fresh-water bivalve, Pyganodon grandis, across a metal contamination gradient. II. Metallothionein response to $\mathrm{Cd}$ and $\mathrm{Zn}$ exposure, evidence for cytotoxicity, and links to effects at higher levels of biological organization. Can J Fish Aquat Sci 52: $703-715$

Couillard Y, Campbell PGC, Tessier A (1993) Response of metallothionein concentrations in a freshwater bivalve (Anotondra grandis) along an environmental cadmium gradient. Limnol Oceanogr 38(2):299-313

Depledge MH (1990) Interactions between heavy metals and physiological processes in estuarine invertebrates. In: Chambers PL, Chambers CM (eds) Estuarine ecotoxicology. JAPAGA, Ashford, p 89-100

Engel DW (1988) The effect of biological variability on monitoring strategies: metallothioneins as an example. Water Resour Bull 24:981-987

Etcheber H (1983) Biogéochimie de la matière organique en milieu estuarien: comportement, bilan, propriétés. Cas de la Gironde. Thèse de Doctorat d'Etat es Sciences, Université de Bordeaux I

Evtushenko ZS, Belcheva NN, Lukyanova ON (1986) Cadmium accumulation in organs of the scallop Mizuhopecten yessoensis. II. Subcellular distribution of metals and metal-binding proteins. Comp Biochem Physiol 83C(2). $377-383$

Evtushenko ZS, Lukyanova ON, Belcheva NN (1990) Cadmium bioaccumulation in organs of the scallop Mizuhopecten yessoensis. Mar Biol 104:247-250

Fowler BA, Engel DW, Brouwer M (1986) Purification and characterization studies of cadmium-binding proteins from the American oyster, Crassostrea virginica. Environ Health Perspect 65:63-69

Frew RD, Hunter KA, Beyer R (1989) Cadmium in the Dredge Oyster Ostrea Lutavia. Dependence on age, body weight and distribution in internal organs. Mar Pollut Bull 20(9): $463-464$

George SG, Olsson PE (1994) Metallothioneins as indicators of trace metal pollution. In: Kramer KJM (ed) Biomonitoring of coastal waters and estuaries. CRC Press, Boca Raton, p 151-178

Hall LW Jr, Anderson RD (1995) The influence of salinity on the toxicity of various classes of chemicals to aquatic biota. Crit Rev Toxicol 25(4):281-346

Johansson C, Cain DJ, Luoma SN (1986) Variability in the fractionation of $\mathrm{Cu}, \mathrm{Ag}$, and $\mathrm{Zn}$ among cytosolic proteins in the bivalve Macoma balthica. Mar Ecol Prog Ser 28 $87-97$

Langston WJ, Zhou M (1987) Cadmium accumulation, distribution and metabolism in the gastropod Littorina littorea: the role of metal-binding proteins. J Mar Biol Assoc UK 67:585-601

Mantoura RFC, Dickson A, Riley JP (1978) The complexation of metals with humic materials in natural waters. Estuar Coast Mar Sci 6:387-408

Martincić D, Nürnberg HW, Branica M (1986) Bioaccumulation of heavy metals by bivalves from Limski kanal (North Adriatic Sea). II. Copper distribution between oysters Ostrea edulis, and ambient water. Mar Chem 18:299-319

Martincić D, Nürnberg HW, Stoeppler M, Branica M (1984) Bioaccumulation of heavy metals by bivalves from Lim Fjord (North Adriatic Sea). Mar Biol 81:177-188
Martincić D. Stoeppler M, Branica M (1987) Bioaccumulation of heavy metals by bivalves from the Limski kanal (North Adriatic Seaj. IV. Zinc distribution between Mytilus galloprovincialis, Ostrea edulis and ambient water. Sci Total Environ 60:143-172

Mason AZ, Jenkins KD (1995) Metal detoxication in aquatic organisms. In: Tessier A, Turner DR (eds) Metal speciation and bioavailability in aquatic systems, Vol 3. John Wiley \& Sons, Chichester, p 479-608

Montgomery DC, Peck EA (1982) Introduction to linear regression analysis. John Wiley \& Sons, New York, p $167-171$

Morrison GMP (1989) Trace element speciation and its relationship to bioavailability and toxicity in natural waters. In: Batley GE (ed) Trace element speciation analytical methods and problems. CRC Press, Boca Raton, p 25-43

Mouneyrac C, Berthet B, Amiard JC, Cosson RP (1995) Caractérisation des composés moléculaires fixant le Cd chez des huitres (Crassostrea gigas) provenant d'un site contaminé. In: Proceedings of the International Symposium. Biological Markers of Pollution. 21-22 Sept 1995. HANPP, Paris, p 47-54

Noel-Lambot F, Bouquegneau JM, Frankenne F, Disteche A (1980) Cadmium, zinc and copper accumulation in limpets (Patella vulgata) from the Bristol Channel with special reference to metallothioneins. Mar Ecol Prog Ser 2 $81-89$

NRC (National Research Council) (1980) The International Mussel Watch. Report of a workshop sponsored by the environmental studies board. Commission Natural Resources. Washington, DC

Pavicic J, Skreblin M, Kregar I, Tuzek-Znidaric M, Stegnar P (1989) Determination of Cd-binding proteins similar to metallothioneins in the digestive gland of Mytilus galloprovincialis in relation to the preliminary treatment of the sample. Period Biol 911:213-224

Phelps HL, Hetzel EW (1987) Oysters size, age, and copper and zinc accumulation. J Shellfish Res 6(2):67-70

Phelps HL, Wright DA, Mihursky JA (1985) Factors affecting trace metal accumulation by estuarine oysters Crassostrea virginica. Mar Ecol Prog Ser 22:187-197

Rainbow PS, Malik I, O'Brien P (1993) Physicochemical and physiological effects on the uptake of dissolved zinc and cadmium by the amphipod crustacean Orchestra gammarellus. Aquat Toxicol 25:15-30

Rajendran N, Tagore J, Kasinathan R (1988) Heavy metal concentrations in oyster Crassostrea madrasensis (Preston) of Cuddalore backwaters, southeast coast of India. Indian J Mar Sci 17:174-175

RNO (1995) Les contaminants dans la matière vivante. In: Anonymous (ed) Surveillance du milieu marin. Min Environ, Paris and IFREMER, Nantes, p 9-24

Roesijadi G (1992) Metallothioneins in metal regulation and toxicity in aquatic animals. Aquat Toxicol 22:81-114

Roesijadi $G$ (1994) Behavior of metallothionein-bound metals in a natural population of an estuarine mollusc. Mar Environ Res 38:147-168

Roesijadi $\mathrm{G}$, Fellingham GW (1987) Influence of $\mathrm{Cu}, \mathrm{Cd}$ and $\mathrm{Zn}$ preexposure on $\mathrm{Hg}$ toxicity in the mussel Mytilus edulis. Can J Fish Aquat Sci 44:680-684

Strong CR, Luoma SN (1981) Variations in the correlation of body size with concentrations of $\mathrm{Cu}$ and $\mathrm{Ag}$ in the bivalve Macoma balthica. Can J Fish Aquat Sci 38:1059-1064

Thompson JAJ, Cosson RP (1984) An improved electrochemical method for the quantification of metallothionein in marine organisms. Mar Environ Res 11:137-152

Thompson M, Wood R (1993) The international harmonized 
protocol for the proficiency testing of (chemical) analytical laboratories. IUPAC/ISO/AOAC, J Pure Appl Chem 65: $2123-2144$

Turner DR, Whitfield M, Dickson AG (1981) The equilibrium speciation of dissolved components in freshwater and seawater at $25^{\circ} \mathrm{C}$ and at $1 \mathrm{~atm}$ pressure. Geochim Cosmochim Acta 45:855-881

Viarengo A, Mancinelli G, Martino G, Muzzucotelli A, Faranda F, Orunesu M (1988) Effects of sublethal copper concentrations, temperature, salinity and oxygen levels on the copper homeostasis and calcium content in the gills of Mytilus galloprovincialis Lam: a multifactorial experiment. Mar Environ Res 24:227-231

Editorial responsibility: Scott Fowler (Contributing Editor), Monaco
Viarengo A, Nott JA (1993) Mechanisms of heavy metal cation homeostasis in marine invertebrates. Comp Biochem Physiol 104C:355-372

Wright DA, Mihursky JA, Phelps HL (1985) Trace metals in Chesapeake Bay oysters: intra-sample variability and its implications for biomonitoring. Mar Environ Res 16: $181-197$

Wright DA, Zamuda CD (1987) Copper accumulation by two bivalve molluscs: salinity effect is independent of cupric ion activity. Mar Environ Res 23:1-14

Zirino A, Yamamoto S (1972) A pH-dependent model for the chemical speciation of copper, zinc, cadmium, and lead in seawater. Limnol Oceanogr 17:661-671

Submitted: April 15, 1997; Accepted: October 30, 1997 Proofs received from author(s): January 19, 1998 